\title{
VIEwPoints
}

\section{Range Readiness Is an Obsolete Management Tool}

\section{Range readiness is an outdated practice forcing rangeland managers into management situations that are detrimental to the natural resource base.}

\section{By B. L. Perryman, W. A. Laycock, L. B. Bruce, K. K. Crane, and J. W. Burkhardt}

\section{Introduction}

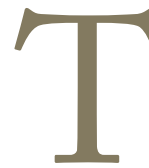

he art and science of range management has benefited greatly from keen observations and thoughtful management guidelines by many rangeland management predecessors. However, as our knowledge and experience advances, it is prudent to revisit even the most well-established and accepted principles of range management. These periodic reevaluations serve to ensure that our rules of thumb remain scientifically sound and applicable within contemporary, ecological knowledge and rangeland management strategies. The following discussion provides a critical evaluation of range readiness, including the evolution, scientific basis, and usefulness of the idea in contemporary rangeland management.

The theory of range readiness evolved early in the 20th century during development of the art and science of range management on western rangelands. Both early and more recent research, along with the invention of specialized grazing systems, have made the application of range readiness not only obsolete but also potentially detrimental to the resource base.

The Society for Range Management defines range readiness as "the defined stage of plant growth at which grazing may begin under a specific management plan without permanent damage to vegetation or soil." The definition also explicitly suggests that range readiness is "usually applied to seasonal range." Using this definition, contemporary usage of range readiness would be to identify the precise moment in spring when plant development has progressed beyond the grazing animals' ability to detrimentally affect the plant. That would be under moderate grazing intensities, and when soil conditions are dry enough to prevent mechanical damage or compaction. Even though the ecological and management conditions under which range readiness evolved are seldom encountered today, the application is still frequently practiced. In fact, we often encounter rangeland managers relying on this rule of thumb to ensure seasonal grazing does

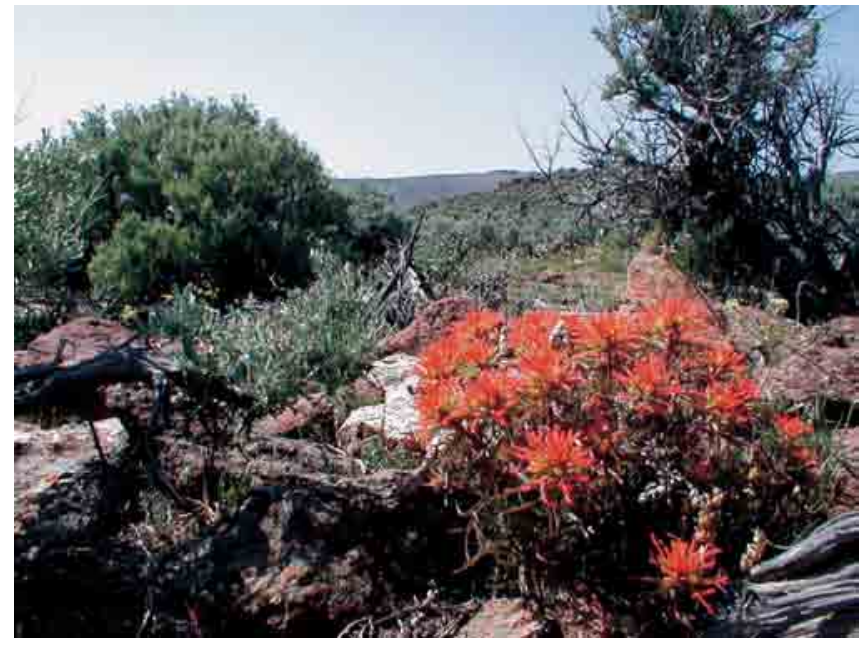

Figure 1. Northern Nevada sagebrush steppe

not damage the vegetation and soil resource. For example, use of range readiness occurs at a number of planning levels including Forest Management Plans, ${ }^{1}$ Allotment Management Plan Environmental Assessments, ${ }^{2}$ Scoping Reports, ${ }^{3}$ Area Activity Plans, ${ }^{4}$ and Allotment Evaluation Recommendations. ${ }^{5}$ Our investigation of the evolution and scientific basis for range readiness shows that the theory was conceived before the presence of widespread, seasonal grazing strategies. Also, indicators were never developed to determine impacts on soil resources.

\section{Development of Range Readiness}

Sampson $^{6}$ may have been the first rangeland ecologist to record development of the range readiness tool. He offered the following observation, "Removal of the herbage year after year during the early part of the growing season weakens the plant, delays the resumption of growth, advances the time of maturity, and decreases the seed production and fertility of the seed." He recommended deferring grazing of a portion of the range each year, initiating grazing after seed 


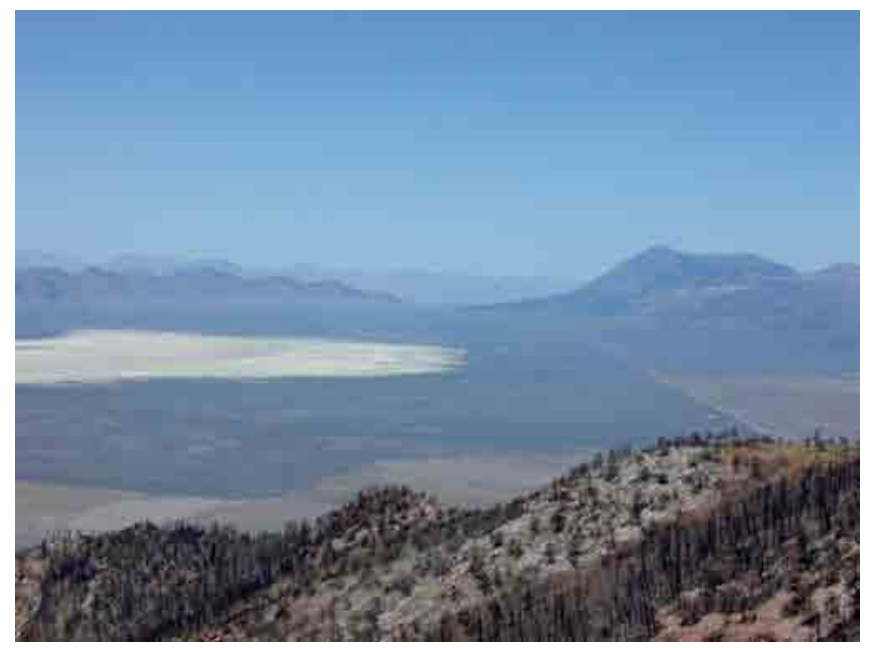

Figure 2. Central Nevada basin and range topography

ripe to "...insure the planting of the seed crop and the permanent establishment of seedling plants without sacrificing the season's forage or establishing a fire hazard."

In a widely used grazing management guide, developed in 1919 for national forestlands, Jardine and Anderson ${ }^{7}$ stated:

Premature grazing was undoubtedly one of the foremost causes of the deterioration of range lands prior to regulated grazing. The damage to forage plants from premature grazing is greatest immediately after growth begins and decreases as the growing season advances...In a broad sense, therefore, grazing at any time before seed maturity of the forage plants may be considered premature.

Jardine and Anderson also recognized that delaying grazing on all rangelands until after seed maturity was not practical and recommended grazing initiation be timed so grazing damage would not be irreparable or out of proportion to the value of the forage. In other words, they recommended grazing be delayed until range readiness was reached, although they did not use the term. Neither Sampson nor Jardine and Anderson discussed or referred to soil conditions and range readiness. Early references to range readiness dealt only with plant growth characteristics and not with soil. Later on, Sampson and Malmsten ${ }^{8}$ defined the time of range readiness as:

the date in any one year when the range first reaches the condition in which there is sufficient feed to keep livestock in thrifty condition and when the stock may be admitted without serious impairment of the growth and reproductive processes of the more important forage plants.

This definition referred only to plant growth stage. Later in the publication, however, Sampson and Malmsten addressed soil conditions, "The opening date of the grazing season for a given range should be based upon the condition of the soil and the development of all of the important for- age species present," and added, "The earliest plants on the range mature early and ... when they are in full bloom, the main forage species are seldom sufficiently developed for grazing and the soil is soft and often boggy."

Range readiness was a useful and effective management tool when it was developed because, at that time, public rangelands (and many private lands as well) were greatly overstocked, and continuous, season-long grazing was the universal strategy. During that era, most rangelands were heavily grazed throughout winter, or winter feeding occurred on or in close proximity to native rangelands. Consequently, livestock had unrestricted access to rangelands, and grazing occurred immediately upon the emergence of new vegetation, with no rest during any time of the year. Depending on the particular area, that grazing strategy may have been practiced for 4 or 5 decades before Sampson's initial publication in 1914. As an example, at the time of the establishment of the Santa Rosa National Forest in 1911 in north-central Nevada, the small mountain range supported approximately 16,000 cattle, 1,500 horses, and 150,000 sheep, grazing all year long, for at least 20 years or more. ${ }^{9}$ Under that scenario, range readiness provided a useful mechanism to delay initiation of intensive, season-long livestock grazing, essentially providing a rudimentary type of rest from intense, heavy grazing.

The emphasis on plant criteria in range readiness led to the development of growth guidelines for different plant species by federal agencies. In 1943, Stoddart and Smith's first range management textbook ${ }^{10}$ published a long list of height or growth stages for a large number of grass, forb, and shrub species to mark when grazing should be initiated. Those guidelines were widely used by the Forest Service in California to determine range readiness. In 1994, Heady and Child ${ }^{11}$ published a later version of range readiness criteria, taken from a California Forest Service District range analysis field guide, which listed growth characteristics of 13 species of grasses, forbs, and shrubs.

All of the early efforts to develop a quantitative way to determine range readiness focused on describing plant growth stages. For example, in 1939 Costello and Price ${ }^{12}$ developed a way to predict range readiness based on the growth stages of major forage species and snowmelt dates. On the sagebrush-grass rangelands of the Snake River Plains of southeastern Idaho, Pechanec and Stewart ${ }^{13}$ stated that after bluebunch wheatgrass leaves reached 2.5 inches, plant growth was sufficient to begin grazing and soil was generally firm enough to prevent compaction or other damage. In the same area, Blaisdell ${ }^{14}$ found that the 2.5 -inch leaf stage was highly correlated with the snowmelt date and the mean daily March temperatures, and so developed a way to predict the date of range readiness from the mean daily March temperatures.

The earliest publications clearly indicate that development of range readiness as a management tool was based on plant-growth stage and not soil characteristics. The contemporary definition and use of range readiness includes both 
vegetation and soil conditions. In practice, this seems logical but was not evident in the earliest literature addressing the range readiness idea. The later works of Costello and Price, ${ }^{12}$ Pechanec and Stewart, ${ }^{13}$ and Blaisdell ${ }^{15}$ represent the first research efforts to develop practical management guidelines based on range readiness. By including references to soil conditions, their works also mark the initial divergence from the original concept that suggested range readiness be based solely on the growth stage of major forage plants and their ability to recover from grazing.

\section{Seasonal Grazing Effects}

In the 1930s, widespread conventional wisdom suggested that early grazing prevented adequate renewal of stored carbohydrates and weakened grass plants. ${ }^{15-17}$ This point was emphasized in Stoddart and Smith's 2nd edition range management text ${ }^{18}$, which stated, "Rapid growth of plants in the spring may temporarily deplete food reserves .... Deferring grazing until the plant has had opportunity to restore these food supplies is advisable." More recent research and reviews ${ }^{19-21}$ suggest that the relationship between carbohydrate storage and grazing is questionable and that widely held theories of food reserves are in need of revision. The contribution of carbohydrate reserves to the leaf regrowth of perennial grasses may be much smaller than previously assumed. Briske ${ }^{20}$ pointed out the difficulty of determining the amount and location of carbohydrate pools in plants, let alone their effects on plant growth. The use of range readiness cannot be based on food-reserve theories.

Sampson and $\mathrm{McCarty}{ }^{15}$ conducted some of the earliest research on the link between plant-growth stage and grazing effects on subsequent growth. They found that grazing or clipping once or twice, early in the growth cycle, had little influence on total annual herbage yield of purple needlegrass in California. They also found that removal of herbage between the time of flower-stalk production and seed maturity inhibited growth. McCarty ${ }^{16}$ concluded that continuous, heavy grazing during flower-stalk formation reduced regrowth more than early, intense use of mountain brome in Utah.

Early research indicated that delaying grazing until forage plants reach early reproductive stages may not be the optimal strategy. McCarty and Price ${ }^{17}$ demonstrated that early season grazing may be more appropriate for total annual forage production. In fact, common control methods such as grazing and burning to reduce or damage perennating buds and reproductive tillers of smooth bromegrass work best if applied at the time of initial tiller elongation. Smooth bromegrass is most vulnerable at this stage. ${ }^{22}$ When grazing initiation (range readiness) dates and sufficiently high grazing intensities coincide with reproductive tiller elongation through the boot stage, productivity of native cool-season grasses can be significantly reduced.

In 1942, McCarty and Price ${ }^{17}$ recommended that grazing be rotated so that no particular portion of the range was grazed at the same time each year to allow for seed produc- tion. That strategy was also recommended to reduce grazing intensities during critical periods of plant growth (ie, during the flowering period). A similar strategy was earlier proposed by Sampson in 1914. ${ }^{6}$ Hormay and Evanko ${ }^{23}$ developed rest-rotation grazing in 1958 "...to provide the amount of rest needed to satisfy the growth requirements of desirable range plants." Since then, rest-rotation grazing has been widely implemented on public and private rangelands, primarily as a strategy to reduce the impacts of grazing during critical periods of plant growth. Rest and rotation ensures that an area will be grazed when grass plants are producing reproductive tillers in only 1 out of 4 years.

Research has shown that early grazing at moderate intensities followed by grazing removal to allow for regrowth provides more benefit than grazing when grass plants are in the reproductive stage. In a 1989 review, Bawtree ${ }^{24}$ concluded that grazing bunchgrasses during the boot stage (the appropriate stage of range readiness) is more damaging than at any other stage of growth. On Forest Service allotments in Montana, in 1994, Lacey and others ${ }^{25}$ found an upward ecological trend in pastures grazed in early spring before tiller elongation. They also found that vegetation changes in early spring pastures were similar to or better than changes in summer pastures. In a 1994 study in the Blue Mountains of Oregon, bluebunch wheatgrass plants, clipped to simulate early spring grazing, developed similarly to unclipped plants because they had sufficient soil moisture and growing season left after clipping. ${ }^{26}$

Bawtree's review ${ }^{24}$ presented a comprehensive discussion about the range readiness concept. One of the major points was that range plants are not damaged by early grazing but rather by grazing intensity. The key was to keep the grazing period short, removing grazing while there was still enough soil moisture left for grass plants to complete the reproduction cycle. Burkhardt ${ }^{27}$ described a naturally occurring system of "functional herbivory" during the Pleistocene and early Holocene periods, before the introduction of domestic livestock. In this system, forage quality and opportunity for forage plants to recover from defoliation were simultaneously optimized through early season grazing. Burkhardt stated, "There does not appear to have been anything in the Pleistocene herbivory that was analogous to our concept of range readiness. Range readiness in the shrub steppe postpones grazing until the critical reproductive period of native bunchgrasses." Burkhardt went on to explain that the natural grazing pattern of native grazers in the western United States was to "follow the green." As soon as snow melts and plant growth was initiated on winter range, animals immediately began to graze new green forage. As the snow melt progressed to higher elevations, herds of native animals moved to obtain newly emerged green forage. Vallentine ${ }^{28}$ described similar situations in the Intermountain West where freeroaming elk generally follow the receding snowline up the mountain in the spring, but livestock are permitted to graze only after range readiness. Burkhard $t^{27}$ also pointed out that 
the vegetation of the Intermountain West evolved with the seasonal migration by now-extinct Pleistocene megafauna as well as surviving species. The vegetation composition of the Intermountain West is essentially the same now as it was when it was grazed by Pleistocene species, ${ }^{29,30}$ and logic dictates that plant communities are adapted to this seasonal migration pattern.

On western public lands, many areas are grazed based only on a system of deferment coincident with range readiness. This includes specific turnout and exit dates with no rotation system. Often, turnout dates correspond to plantgrowth stages that are most detrimental to key grass species. Earlier turnout dates combined with exit dates before soilmoisture depletion and hot temperatures would be more appropriate for plant health and vigor. Earlier turnout and exit dates would also improve animal distribution, reducing riparian impacts that generally occur during the hot season. ${ }^{31}$ This approach would also provide the potential to return for a late-season grazing period after seed set.

Application of range readiness also fails to recognize differential responses to grazing by different forage species. For example, Caldwell and Richards ${ }^{32}$ demonstrated that crested wheatgrass is much less sensitive to early grazing than bluebunch wheatgrass, and they also provide physiological reasons for this difference. In 1967, Hedrick ${ }^{33}$ reported that heavy grazing in April and May of crested wheatgrass in southeastern Oregon resulted in considerable more green regrowth and better seed production, which meant a potential early turnout the subsequent year. Yet where range readiness grazing turnout is practiced, agency field guidelines often make no distinctions, applying the same range readiness criteria across all species.

\section{Potential Soil Impacts}

In the 1980s, rangeland ecologists and management agencies began to recognize the potential for livestock grazing to negatively impact certain soil characteristics. The body of research addressing soil impacts and livestock grazing is substantial. ${ }^{34-37}$ General conclusions across all grazing systems indicate that heavy stocking rates negatively affect infiltration rates and soil structure while increasing bulk densities. Often, these are only growing season effects that are alleviated by freeze-thaw processes the following winter. Effects are also variable with respect to soil type and precipitation patterns. However, with respect to range readiness, no specific quantitative soil moisture guidelines have been developed.

The greatest potential for negative soil impacts occurs when soil moisture levels are just below the saturation point. Even at the time of snowmelt, many western rangeland areas never approach this level of soil moisture content. Many ecological sites are also characterized by soils with coarse-fragment inclusions. On these sites, snowmelt rates seldom exceed infiltration rates, ${ }^{38}$ limiting the time soils would be susceptible to negative impacts from large grazing animals. Concerns about soil damage from early grazing may not be

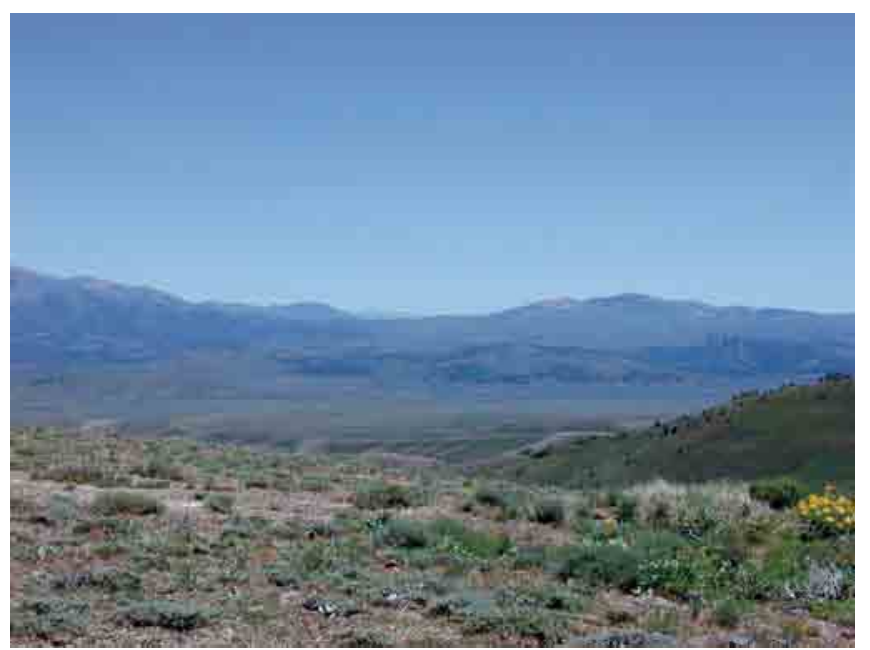

Figure 3. University of Nevada-Reno Gund Ranch near Austin, NV

warranted in many situations, particularly if animal distribution is good, indicating that the soil condition part of the range readiness concept may be overemphasized in many management scenarios.

\section{Management Implications}

Over time, as rotation systems (deferred rotation, rest rotation, etc) have been implemented, we have gained a better understanding of the interrelationships between grazing and plant-growth stage. Because of this, the range readiness idea has become less important as a management tool. On any rangeland, with rotational deferment built into the grazing system, use of range readiness to determine initiation of grazing in the first pasture may actually be detrimental to plant health. Initiating grazing much earlier in the first pasture, followed by earlier livestock removal, and rotating the use of the first pasture each year may be a better strategy for plant and ecosystem health.

On western ranges where areas are grazed based only on a system of deferment coincident with range readiness and no rotation, turnout dates should be arranged for earlier use to avoid use during the reproductive tiller development stages. Early use should be followed by early removal. By the time of range readiness, upland plants are beginning to mature, and grazing animals switch their preference to riparian areas. Earlier turnout dates combined with exit dates before soil moisture depletion and hot temperatures would be more appropriate for plant health and vigor and would also improve animal distribution, reducing riparian impacts that generally occur during the hot season. This approach would also provide the potential to return for a late-season grazing period after seed set. Managers may also need to adjust animal numbers up or down to achieve distribution and use goals because earlier turnouts will probably have an effect on foraging behavior.

One additional aspect of range readiness-making sure that there is enough forage to sustain livestock once they are turned out-is still valid in view of animal performance. ${ }^{39}$ 
Early cattle and sheep foraging will include both new growth and residual growth from the previous year. Early research from the 1920s and 1930s demonstrated that the combination provides an adequate nutritional base. ${ }^{15,17}$ Ensuring adequate residue to support early grazing usually is not a problem on rangelands that have been moderately or lightly grazed the previous year. Earlier turnout and removal dates may also necessitate changes in calving dates and location of calving operations. These are questions and scenarios that need to be discussed with grazing permittees on an individual basis. Some operations may be better suited to season-ofuse changes than others. Bawtree ${ }^{24}$ suggested that economic, animal nutrition, and rangeland ecology research all support the concept that grazing and removing animals early helps ensure resource health.

The range readiness tool is widely used on western rangelands today, even though research has demonstrated potential negative effects on forage grass species. Research has not effectively addressed potential soil impacts when range readiness is practiced. In general, rotational-grazing strategies effectively address the concern of severe, repeated defoliation of forage plants during critical growth stages. However, rangeland managers continue to use the range readiness tool to manage grazing at an individual plant scale across large spatial areas. Tools like range readiness were developed at a time when rangeland managers did not have the authority, experience, or scientific research on which to base grazing management. Today, we have the authority, knowledge, and experience to effectively manage livestock grazing at a landscape scale. Yet, even in the presence of proven, successful grazing management strategies, best management practices continue to be plagued by rule-of-thumb measures, applied too broadly, with little relationship to management objectives.

Range readiness was a useful and practical management guideline for the era in which it was developed. The original objective of range readiness- -avoiding permanent damage to vegetation or soil"-remains integral to meeting natural resource objectives through sound grazing management strategies. However, it is apparent that range readiness may no longer be an appropriate tool to meet this objective. We suggest that the range may always be "ready" provided that sufficient forage is present to sustain grazing animals and that it can be demonstrated that the existing grazing management strategy results in progress toward long-term plant community objectives.

Planning documents should provide rangeland managers with the flexibility to tailor turnout and exit dates to specific areas and permittee operations rather than focusing on regulating allotment or district-wide specifications and standards. Where range readiness is an appropriate tool, it should be employed; where it is detrimental, it should be rejected; and a discussion of the idea should be revisited by land managers and scientists alike. The appropriate question may not be "is the range ready?" but rather "is the rangeland manag- er ready?" Are we ready, when appropriate, to abandon cookbook approaches in exchange for on-the-ground applications of up-to-date ecological knowledge and experience? It is our assertion that rangeland managers are indeed ready and, in fact, have repeatedly demonstrated successful grazing management through communication, innovation, and sound application of ecological principles. Hopefully, this will be the approach embraced by authors of planning documents and rangeland managers in the future. Managers need the flexibility to reject inappropriate or outdated tools and concepts, leaving them in the past where they belong instead of attempting to apply them to situations where they no longer have relevance.

Authors are Associate Professor, Department of Animal Biotechnology, University of Nevada-Reno, Reno, NV 89557 (Perryman); Rangeland Consultant, Laramie, WY 82072 (Laycock); Associate Professor, Department of Animal Biotechnology, University of Nevada-Reno, Reno, NV 89557 (Bruce); Rangeland Consultant, Prineville, OR 97754 (Crane); and Rangeland Consultant, Indian Valley, ID 83632 (Burkhardt).

\section{References}

1. USDA Forest Service. 2001. Sierra Nevada forest plan amendment, final environmental impact statement, January 2001. Pacific Southwest Region, Vallejo, CA: USDA.

2. USDA Forest SERVICE. 1999. Environmental assessment, allotment management plans for Chevelon Canyon, Clear Creek, Limestone, and Wallace allotments, Chevelon/Heber Ranger Districts, Apache-Sitgreaves National Forest, Overgaard, AZ: USDA.

3. USDA Forest SERVICE. 1998. Scoping report-Allotment management plans, Chevelon/Heber Ranger District, ApacheSitgreaves National Forest, Overgaard, AZ: USDA.

4. Bureau of Land Management. 2000. Draft environmental impact statement for the Jack Morrow Hills coordinated activity plan. Rock Springs, WY: BLM.

5. Bureau of Land Management. 1997. Grass Valley Allotment Evaluation, Battle Mountain District, NV: BLM.

6. SAMPSON, A. W. 1914. Natural revegetation of rangelands based upon growth requirements and life history of the vegetation. Journal of Agricultural Research 3:93-148.

7. Jardine, J. T., AND M. Anderson. 1919. Range management on the national forests. Washington, DC: US Department of Agriculture. Bulletin 790.

8. Sampson, A. W., And H. E. Malmsten. 1926. Grazing periods and forage production on the national forests. US Department of Agriculture. Bulletin 1405.

9. USDA ForEST SERVICE. 2004. Draft environmental impact statement, Martin Basin rangeland project. Santa Rosa Ranger District Humbolt-Toiyabe National Forest, Winnemucca, NV: USDA.

10. Stoddart, L. A., AND A. D. Smith. 1943. Range management. 1st ed. New York, NY: McGraw-Hill. 
11. Heady, H. F., AND R. D. CHILD. 1994. Rangeland ecology and management. Boulder, CO: Westview Press.

12. Costello, D. F., AND R. Price. 1939. Weather and plantdevelopment data as determinants of grazing periods on mountain range. Washington, DC: US Department of Agriculture. Technical Bulletin 686.

13. Pechanec, J. F., And G. Stewart. 1949. Grazing spring-fall sheep ranges of southern Idaho. US Department of Agriculture. Circular 808.

14. Blaisdell, J. P. 1958. Seasonal development and yield of native plants on the upper Snake River Plains and their relation to certain climatic factors. Washington, DC: US Department of Agriculture. Technical Bulletin 1190.

15. Sampson, A. W., AND E. C. MCCarTy. 1930. The carbohydrate metabolism of Stipa pulchra. Hilgardia 5:61-100.

16. MCCARTY, E. C. 1938. The relation of growth to the varying carbohydrate content in mountain brome. US Department of Agriculture. Technical Bulletin 598.

17. MCCARTy, E. C., AND R. PRICE. 1942. Growth and carbohydrate content of important mountain forage plants in central Utah as affected by clipping and grazing. US Department of Agriculture. Technical Bulletin 818.

18. Stoddart, L. A., And A. D. Smith. 1955. Range management. 2nd ed. New York, NY: McGraw-Hill.

19. BRISKE, D. D. 1991. Developmental morphology and physiology of grasses. In: R. K. Heitschmidt and J. W. Stuth [eds.]. Grazing management: An ecological perspective. Portland, OR: Timber Press. p 85-108.

20. BRISKe, D. D., AND J. H. Richards. 1994. Physiological responses of individual plants to grazing: current status and ecological significance. In: M. Vavra, W. A. Laycock, and R. D. Pieper [eds.]. Ecological implications of livestock herbivory in the west. Denver, CO: Society for Range Management. p 147-176.

21. CALdWELL, M. M. 1984. Plant requirements for prudent grazing. In: Developing strategies for rangeland management. Boulder, CO: Westview Press. p 117-152

22. Stacy, M. D., B. L. Perryman, P. D. Stahl, and M. A. SMITH. Brome control and microbial inoculation effects in reclaimed cool-season grasslands. Rangeland Ecology and Management 58:161-166.

23. Hormay, A. L., AND A. B. EvanKo. 1958. Rest-rotation grazing, a management system for bunchgrass ranges. USDA Forest Service California Forest and Range Experiment Station. Misc. Paper No. 27.

24. Bawtree, A. H. 1989. Recognizing range readiness. Rangelands 11:67-69.

25. Lacey, J., S. Studinger, And R. Hecker. 1994. Early spring grazing on native range. Rangelands 16:231-233.

26. Westonskow-Wall, K. J., W. C. Krueger, L. D. Bryant, AND D. R. Thomas. 1994. Nutrient quality of bluebunch wheatgrass regrowth on elk winter range in relation to defoliation. Journal of Range Management 47:240-244.

27. BurkHARDT, J. W. 1996. Herbivory in the Intermountain West. Moscow: Idaho Forest, Wildlife, and Range Experiment Station. Bulletin 58.

28. Vallentine, J. F. 1990. Grazing management. San Diego, CA: Academic Press.

29. Barnosky, C. W., P. M. Anderson, and P. J. Bartleim. 1987. The northwestern U.S. during deglaciation: Vegetational history and paleoclimate implications. In: W. F. Ruddiman and H. E. Wright, Jr. [eds.]. North America and adjacent oceans during the last deglaciation. Vol. K-3 of The geology of North America. Boulder, CO: The Geological Society of America.

30. Tidwell, W. D., S. R. Rushforth, and D. Simper. 1972. Evolution of floras in the Intermountain region. In: A. Cronquist, A. H. Holmgren, H. H. Holmgren, and J. L. Reveal [eds.]. Intermountain flora. Vol. 1. New York, NY: Hafner Publishing Co.

31. Swanson, S. R., AND D. ToRELL. 1990. Riparian grazing management: An alternative to range readiness. Reno, NV: University of Nevada. Nevada Cooperative Extension Fact Sheet 90-25.

32. Caldwell, M. M., AND J. H. Richards. 1986. Competitive position of species in respect to grazing tolerance: Some perspective on ecophysiological processes. In: Proceedings of the 2nd International Rangeland Congress. Canberra: Australian Academy of Science, p 447-449.

33. HEDRICK. D. W. 1967. Managing crested wheatgrass for early spring use. Journal of Range Management 20:53-54.

34. Abdel-Magib, A. H., G. E. Schuman, and R. H. Hart. 1987. Soil bulk density and water infiltration as affected by grazing systems. Journal of Range Management 40:307-310.

35. Naeth, M. A., R. L. Rothwell, D. S. Chanasyk, And A. W. BAILEY. 1990. Grazing impacts on infiltration in mixed prairie and fescue grassland ecosystems of Alberta. Canadian Journal of Soil Science 70:593-605.

36. Pluhar, J. J., R. W. Knight, and R. K. Heitschmidt. 1987. Infiltration rates and sediment production as influenced by grazing systems in the Texas Rolling Plains. Journal of Range Management 40:240-243.

37. Thurow, T. L., W. H. Balckburn, and C. A. TaYlor, JR. 1986. Hydrologic characteristics of vegetation types as affected by livestock grazing systems, Edwards Plateau, Texas. Journal of Range Management 39:505-508.

38. TABleR, R. D. 1985. Ablation rates of snow fence drifts at 2,300 meter elevation in Wyoming. Proceedings of the 53rd Annual Western Snow Conference; 16-19 April 1985; Boulder, CO. Soda Springs, CA: WSC. p 1-12.

39. SHARP, L. A. 1970. Suggested management programs for grazing crested wheatgrass. University of Idaho, College of Forestry, Wildlife and Range Science, Bulletin 4. 